\title{
EFEKTIVITAS PERKULIAHAN ONLINE DI MASA PANDEMI COVID-19 PADA MAHASISWA UAD WATES
}

\author{
Irsyaadul 'Ibaad', Unik Hanifah Salsabila², Muhammad Fatahillah³, Adam \\ Baustin Erlangga ${ }^{4}$, Faisal Abyan Hanif ${ }^{5}$ \\ 1,2,3,4,5Universitas Ahmad Dahlan Yogyakarta \\ E-mail: irsyaadul1811331037@webmail.uad.ac.id
}

\begin{abstract}
The Covid-19 outbreak provided surprises and also provided challenges for various educational institutions, including universities. The government has banned universities from conducting face-to-face lectures. The government has issued a policy for implementing temporary courses online (Ministry of Education and Culture Dikti Circular No.1 2020). All universities are required to be able to conduct online or online learning. This study aims to determine the effectiveness of online lectures during the Covid-19 Pandemic for UAD Wates Islamic Religious Education students. This research method uses descriptive analysis method through a survey with a google form questionnaire which is conducted online. The sample in this study were students of UAD Wates class of 2017, 2018, and 2020. The respondents in this study were 15 respondents. The effectiveness of online lectures during the Covid-19 Pandemic for students at UAD Wates was quite effective in preventing the transmission of the Covid-19 virus. However, the results of the study also show that online lectures have not been running effectively, because there are still lecturers who do not conduct online lectures. The learning method used is still dominant with assigning assignments to students so that many students are overwhelmed in doing coursework.
\end{abstract}

Keywords: effectiveness, online lectures, Covid-19

Abstrak: Wabah Covid-19 memberikan kejutan dan juga memberikan tantangan bagi berbagai lembaga pendidikaan, tidak terkecuali Perguruan Tinggi. Pemerintah sudah melarang perguruan tinggi dalam melaksanakan perkuliahan secara tatap muka. Adapun pemerintah mengeluarkan kebijakan dalam penyelernggaraan perkuliahan untuk sementara dilaksanakan secara daring (Surat Edaran Kemendikbud Dikti No.1 tahun 2020). Seluruh perguruan tinggi dituntut untuk dapat menyelenggarakan pembelajaran secara daring atau online. Penelitian ini bertujuan untuk mengetahui efektivitas perkuliahan online di masa Pandemi Covid-19 pada mahasiswa UAD Wates. Metode penelitian ini menggunakan metode analisis deskriptif melalui survei dengan kuesioner google form yang dilakukan secara online. Sampel pada penelitian ini adalah mahasiswa UAD Wates angkatan 2017, 2018, dan 2020. Responden pada penelitian ini sebanyak 15 responden. Efektivitas perkuliahan online di masa Pandemi Covid-19 pada mahasiswa UAD Wates cukup efektif untuk mencegah penularan virus Covid-19. Akan tetapi hasil penelitian juga menunjukkan bahwa perkuliahan online ini belum berjalan secara efektif, karena masih ada dosen yang tidak menjalankan perkuliahan secara online. Metode pembelajaran yang digunakan pun masih dominan dengan pemberian tugas kepada mahasiswa sehingga banyak mahasiswa yang kewalahan dalam mengerjakan tugas kuliah.

Kata Kunci: Efektivitas, perkuliahan online, Covid-19 


\section{PENDAHULUAN}

Saat ini, Indonesia masih terkena dampak dari pandemi covid-19. Dampak ini bukan hanya di Indonesia, tetapi secara global di seluruh dunia,(Putri, 2020) lebih tepatnya 215 negara didunia.(Firman \& Rahayu, 2020) Banyak aspek yang terdampak, seperti dalam aspek sosial, pendidikan, kesehatan, ekonomi dan lain lain. Dalam aspek sosial misalnya masyarakat bisa lebih peka dan tolong menolong untuk sesama, didalam bidang kesehatan dampaknya ialah orang bisa terpapar Covid-19 ini. Covid-19 juga membuat khawatir semua orang karena virus ini bisa menyerang siapa saja, terlebih kasus Covid-19 di Indonesia semakin kesini semakin meningkat. Dari aspek ekonomi harga barang dan bahan kebutuhan pokok meningkat, restoran dan rumah makan juga tidak melayani makan ditempat. Dibidang pariwisata, tempattempat hiburan dan destinasi-destinasi liburan ditutup.

Masa-masa seperti ini yaitu pandemi covid-19 memberikan tantangan tersendiri bagi berbagai sektor dan lembaga termasuk sektor pendidikan, khususnya dalam hal ini perguruan tinggi. Pemerintah Indonesia berusaha protektif dengan hal hal yang dikhawatirkan akan menimbulkan penyebaran covid-19 ini semakin luas. Pemerintah sudah membuat aturan-aturan agar dapat menekan penyebaran pandemi covid-19 seperti melarang untuk bekerumun, dianjurkan untuk menjaga jarak, selalu memakai masker setiap keluar rumah maupun selalu mencuci tangan. Adapun untuk saat ini, kebijakan yang diberlakukan untuk segala jenjang pendidikan masih menggunakan pembelajaran secara daring, mulai dari SD, SMP, SMA dan juga perguruan tinggi. Pemerintah telah melarang untuk berkerumun, menjaga jarak, memakai masker dan selalu mencuci tangan. Untuk saat ini, pemerintah melarang perguruan tinggi untuk melangsungkan perkuliahan tatap muka, maka untuk sementara di masa pandemi covid-19 ini perkuliahan dilaksanakan secara daring. Perguruan tinggi dituntut untuk dapat menyelenggarakan dan melaksanakan perkuliahan secara daring atau online.(Firman \& Rahayu, 2020).

Tidak sedikit universitas yang merespon dengan cepat instruksi pemerintah untuk menyelenggarakan perkuliahan secara daring. Begitu juga Universitas Ahmad Dahlan, Wakil Rektor 2 mengeluarkan surat edaran tentang perkuliahan terkait tindakan preventif terhadap Covid-19, guna untuk mengantisipasi penyebaran Covid-10 dilingkungan Universitas Ahmad Dahlan. Dalam surat edaran tersebut berisikan instruksi untuk melakukan pembelajaran daring dan kebijakan bagi mahasiswa yang mengambil mata kuliah praktikum.

Tentu saja kebijakan tersebut menimbulkan pro dan kontra bagi seluruh civitas akademika kampus, terutama bagi mahasiswa dan dosen. Kebijakan ini dinilai tidak efisien untuk dalam pembelajaran, terutama dalam perkuliahan. Kebijakan ini dinilai akan mempersulit mahasiswa dalam memahami materi, atau mahasiswa tidak dapat memahami secara maksimal. Adapun pembelajaran daring ini akan membuat kurangnya konsentrasi mahasiswa dalam proses pembelajaran.

Efektivitas dalam pembelajaran sangat harus diperhatikan dan dipertimbangkan dalam proses pembelajaran untuk mencapai tujuan-tujuan yang sudah ditetapkan. Dalam proses pembelajaran ada beberapa ciri-ciri keefektifan program pembelajaran seperti, berhasil mengantarkan siswa dalam mencapati tujuan-tujuan intruksional yang telah ditetapkan, dapat memberikan pengalaman 
belajar atraktif kepada siswa, melibatkan siswa secara aktif sehingga dapat membantu pencapaian tujuan intruksional tersebut dan mempunyain sarana prasarana untuk menunjang proses pembelajaran.(Rohmawati, 2015)

Menurut Nguyen dalam Hikmat, keefektifan program pembelajaran tidak hanya ditinjau dari segi tingkat prestasi belajar saja, akan tetapi harus ditinjau dari segi proses dan sarana penunjang yang ada. Efektivitas metode pembelajaran merupakan suatu ukuran yang berhubungan dengan tingkat keberhasilan dari suatu proses pembelajaran. (Hikmat et al., 2020). Artikel ini akan menganalisa masalah efektivitas perkuliahan online selama pandemi covid-19 dari perspektif mahasiswa, Universitas Ahmad Dahlan, kampus VI (Wates).

\section{METODE}

Penelitian ini menggunakan analisis deskriptif yang akan mengkaji perspektif para mahasiswa di Universitas Ahmad Dahlan (UAD), kampus VI (Wates) mengenai efektivitas perkuliahan online selama Pandemi Covid-19. Penelitian ini tentu saja menggunakan beberapa pendektaan seperti gaya belajar, jenis-jenis komunikasi dan juga media yang digunakan mahasiswa dalam proses pembelajaran daring. Subjek penelitiannya adalah mahasiswa UAD Wates yang telah melaksanakan perkuliahan daring dan dikelompokkan berdasarkan respon subjek penelitian. Dalam penelitian ini didapatkan 15 mahasiswa sebagai subjek penelitian dengan rincian lima mahasiswa dengan tahun masuk 2017, lima mahasiswa dengan tahun masuk 2018 dan lima mahasiswa dengan tahun masuk 2019. Adapun dalam penelitian ini jumlah mahasiswa ada lima belas dan mahasiswi ada lima.
Vol. 2 No. 1, Januari 2021

Penelitian ini dilaksanakan dengan mengumpulkan data primer dengan cara membagikan dan menyebarkan kuisioner secara online melalui media sosia Whatsapp. Adapun pengumpulan data sekunder dalam penelitian inin yaitu dengan studi literatur unutuk mencari sumber dokumen dan artikel terkait yang berkaitan dengan gambaran dan pemaparan perkuliahan daring atau online untuk memperkuat teori yang ada dalam penelitian ini.

\section{HASIL}

1. Media Pembelajaran Dalam Perkuliahan Daring yang Digunakan UAD Wates

Gambar 1.Media pembelajaran dalam perkuliahan online yang digunakan UAD Wates

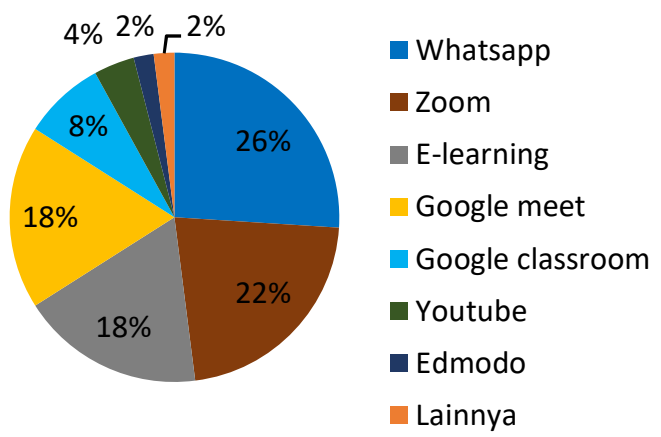

Berdasarkan data dari angket, sesuai dengan diagram di atas diperoleh informasi tentang media dan aplikasi yang digunakan dalam proses perkuliahan daring yaitu sebanyak $26 \%$ mahasiswa menyatakan bahwa mereka menggunakan aplikasi Whatsapp sebagai media pembelajaran dalam proses perkuliahan. Media dapat diartikan sebagai segala sesuatu yang dapat memberikan dan menyalurkan informasi kepada penerima informasi.(Muhson, 2010). Kemudian pembelajaran sendiri pada dasarnya adalah proses penambahan informasi dan pengembangan kemampuan kognitif, afektif 
dan psikomotor.(Abidin, 2017) Jadi media pembelajaran adalah segala sesuatu yang digunakan dalam proses penyampaian informasi dari pendidik kepada peserta didik pada waktu pembelajaran berlangsung. Sebagian besar mahasiswa memilih menggunakan aplikasi Whatsapp sebagai media pembelajaran karena mahasiswa sudah sangat mengenal aplikasi ini, selain itu semua fitur-fitur aplikasi Whatsapp dapat memudahkan dosen maupun mahasiswa untuk mengirim dan menerima materi perkuliahan.

Kemudian sebanyak $22 \%$ mahasiswa menggunakan aplikasi zoom untuk hadir pada perkuliahan melalui video conference yang yang real time, sehingga bisa menyimak penjelasan dan bertatap muka dengan dosen meskipun melalui media online. $18 \%$ mahasiswa mengikuti perkuliahan menggunakan aplikasi Elearning dan dalam pesentase yang sama yaitu $18 \%$ mahasiswa menggunakan aplikasi Google Meet. Selanjutnya sebanyak 16\% mahasiswa lagi menyatakan bahwa mereka mengikuti perkuliahan dengan menggunakan aplikasi Google Classroom, Youtube, Edmodo dan lainnya.

2. Pengetahuan Mahasiswa Mengenai Media Pembelajaran Daring

\section{Gambar 2.Pengetahuan Mahasiswa UAD} Wates Mengenai Media Pembelajaran Daring

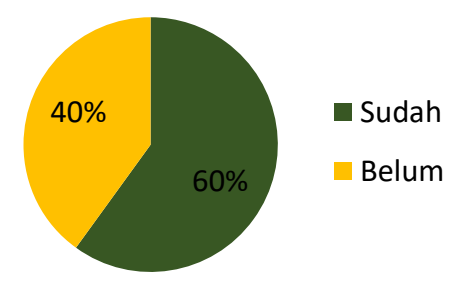

Berdasarkan grafik di atas, dapat diketahui bahwa sebanyak 60\% mahasiswa UAD Wates sudah mengetahui media
Vol. 2 No. 1, Januari 2021

pembelajaran yang digunakan dalam proses perkuliahan online, media pembelajaran yang dimaksud adalah Whatsapp, Zomm, E-learning, Google Meet, Google Classroom dan lainnya. Sedangkan 40\% mahasiswa lagi sebelumnya belum mengetahui media pembelajaran tersebut. Akan tetapi, menurut sebagian mahasiswa perkuliahan online ini memberikan dampak positif bagi setiap individu mahasiswa. Karena dengan perkuliahan online ini mahasiswa menjadi lebih aktif untuk mencari tahu mengenai banyak hal, salah satunya yaitu mencari tahu bagaimana cara menggunakan mediamedia pembelajaran online.

3. Persiapan Mahasiswa UAD Wates Dalam Mengikuti Perkuliahan Online

Gambar 3.Persiapan Mahasiswa Pendidikan Agama Islam UAD Wates Dalam Mengikuti Perkuliahan Online

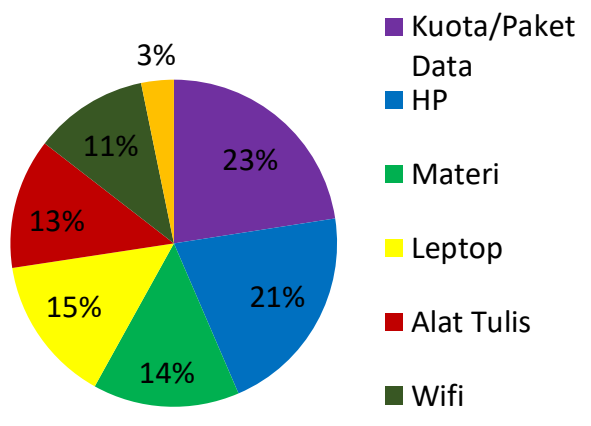

Pada kenyataannya kesiapan mahasiswa dalam mengikuti perkuliahan daring jauh dari harapan. Pasalnya sistem online ini menuntut kemandirian belajar yang tinggi pada setiap mahasiswa. Dari grafik di atas kita ketahui bersama bahwa $22 \%$ mahasiswa menyatakan hal yang paling utama dipersiapkan oleh mahasiswa untuk mengikuti perkuliahan online adalah kuota atau paket data. Padahal di sisi lain teknis penyebaran jaringan internet belum merata. Hal ini dapat terlihat dan dirasakan ketika mahasiswa pulang ke 
daerah asalnya dan mendapati begitu susahnya mendapatkan koneksi internet yang stabil. Kemudian sebanyak 21\% mahasiswa menyatakan bahwa hal yang perlu dipersiapkan selanjutnya adalah Handphone (HP), sebagai salah satu alat untuk dapat mengikuti perkuliahan online. Beruntungnya Handphone android saat ini sudah dilengkapi dengan fitur-fitur yang mendukung adanya pendidikan secara online, seperti berbagai aplikasi Microsoft office yang dapat diinstal di android, aplikasi video converence berupa zoom, google meet dan lain-lain. Sehingga bagi mahasiswa yang tidak atau belum memiliki leptop tetap bias mengikuti perkuliahan dengan baik.

Setelah mempersiapkan kuota atau paket data dan handphone selanjutnya menurut $\quad 15 \% \quad$ mahasiswa juga mempersiapkan materi kuliah, sehingga mahasiswa tidak hanya asal presensi kehadiran saja, akan tetapi juga tetap menyimak serta mempelajari materi-materi kuliah yang sudah disampaikan sebelumnya oleh dosen pada setiap mata kuliahnya. Selebihnya sebanyak 14\% mahasiswa yang memiliki leptop juga mempersiapkan leptopnya untuk mengikuti perkuliahan online. $\quad 14 \% \quad$ lagi mempersiapkan alat tulis untuk mencatat materi-materi nyang di sampaikan oleh dosen. 11\% mahasiswa mempersiapkan wifi untuk meminimalisir terjadinya ketidak stabilan jaringan internet dari kartu perdana yang digunakan, mereka juga mengatakan lebih suka mengerjakan tugas diteras kampus meskipun kampus dalam keadaan ditutup karena jaringan internet dari wifi kampus cukup kuat dan stabil.
Vol. 2 No. 1, Januari 2021

4. Tempat Mahasiswa UAD Wates Mengikuti Perkuliahan Online Gambar 4. Tempat Mahasiswa Pendidikan Agama Islam UAD Wates Mengikuti Perkuliahan Online Perkuliahan online memang dapat

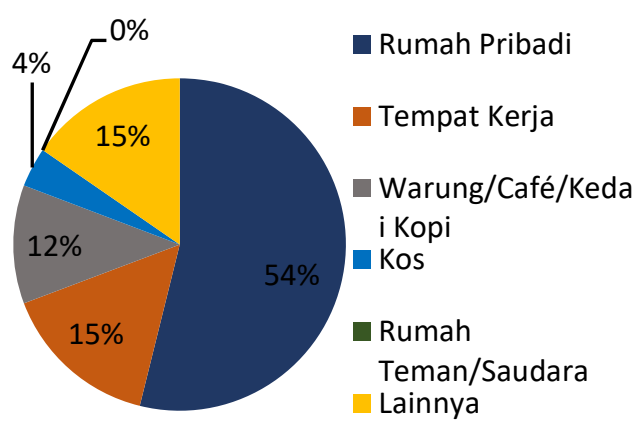

diakses dimana saja dan diwaktu yang telah ditentukan bersama. Mahasiswa juga dapat melakukan perkuliahan dengan lebih santai dan tenang. Dengan keadaan masing-masing setiap mahasiswa dapat ikut perkuliahan secara daring. Dari grafik di atas dapat kita ketahui bahwa sebanyak $52 \%$ mahasiswa mengikuti perkuliahan online dirumah masing-masing sesuai dengan kebijakan pemerintah untuk belajar dari rumah. Dan bagi 15\% mahasiswa yang kuliah sambil bekerja untuk membiayai kuliahnya sendiri mereka mengikuti perkuliahan online dengan tetap berada di tempat kerja, yaitu disela-sela jam istirahat atau bahkan jika memang jadwalnya bertabrakan mereka pun mampu bekerja sambil kuliah pada waktu yang bersamaan.

Perkuliahan daring memang memberikan waktu yang lebih luang kepada sebagian mahasiswa, akan tetapi tidak bisa dipungkiri, bahwa sebagian mahasiswa lainnya tidak bisa merasakan kenikmatan dari kuliah daring, mereka mengeluh bosan dengan sistim perkuliahan online seperti saat ini. Sehingga untuk mengurangi kebosanan, $12 \%$ mahasiswa 
mengikuti perkuliahan dengan berada di luar rumah, seperti warung-warung, cafécafe dan kedai-kedai kopi. Selebihnya beberapa mahasiswa juga mengikuti perkuliahan online di kos dan tempattempat lainnya.

5. Tingkat Pemahaman Mahasiswa Terhadap Materi yang Disampaikan Dosen Dalam Perkuliahan Online

Gambar 5. Tingkat Pemahaman

Mahasiswa Terhadap Materi Yang Disampaikan Dosen Dalam Perkuliahan Online

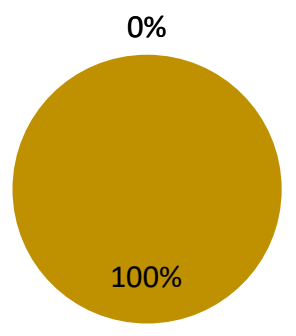

- Tidak faham sama sekali

- Sedang (Terkadang faham, terkadang tidak)

Sangat faham

Dapat dipastikan bahwa perkuliahan daring dengan memanfaatkan aplikasiaplikasi online ini memiliki dampak kepada sistem pendidikan di Indonesia karena sebelumnya mahasiswa sangat jarang melaksanakan kuliah secara online. Hal yang sangat terpengaruh adalah tingkat pemahaman mahasiswa terhadap materi yang disampaikan oleh dosen. Sesuai dengan diagram di atas, dapat kita ketahui secara jelas bahwasanya 100\% mahasiawa terkadang paham dengan materi yang disampaikan oleh dosen, akan tetapi terkadang juga tidak paham, terutama materi yang baru pertama kali mereka pelajari.

Kemudian dengan tidak adanya pembelajaran tatap muka dan ketidaksiapan dosen memberikan perkuliahan secara online, dosen mengganti pembelajaran tersebut dengan lebih banyak memberikan tugas-tugas kepada mahasiswanya. Hal inilah yang sering dikeluhkan oleh mahasiswa, karena padatnya porsi tugas dengan deadline tugas
Vol. 2 No. 1, Januari 2021

yang berdempetan antar setiap mata kuliah membuat mahasiswa kelelahan dan kewalahan dalam mengerjakan tugas-tugas tersebut.

6. Jenis Komunikasi Daring yang Diminati Mahasiswa UAD Wates

Gambar 6.Jenis Komunikasi Daring yang Diminati Mahasiswa UAD Wates

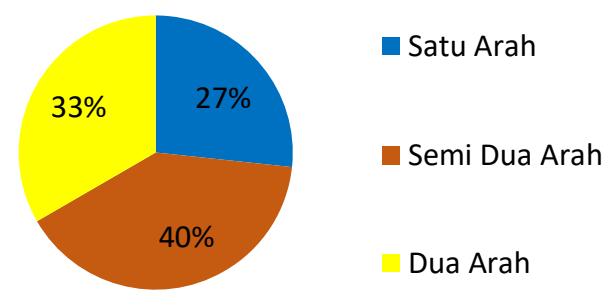

Berdasarkan grafik di atas dapat diketahui bahwa 40\% mahasiswa lebih menyukai model komunikasi semi dua arah UAD Wates yaitu melalui media chatroom dengan aplikasi Whatsapp. Model komunikasi ini lebih diminati oleh sebagian besar mahasiswa karena mahasiswa sudah sengat paham dan sudah terbiasa menggunakan aplikasi Whatsapp dalam kehidupan sehari-hari. Hal ini sesuai dengan besarnya persentase penggunaan Whatsapp sebagai media pembelajaran di perkuliahan online.

Kemudian sebanyak $33 \%$ mahasiswa menyukai sistem komonukasi dua arah, seperti vivido conference, yang pada umumnya menggunakan aplikasi Zoom dan Google Meet, dan 27\% mahasiswa lainnya menyukai sistem komunikasi satu arah seperti materi video yang dikirim atau diunggah oleh dosen ke berbagai media pembelajaran daring yang digunakan. 


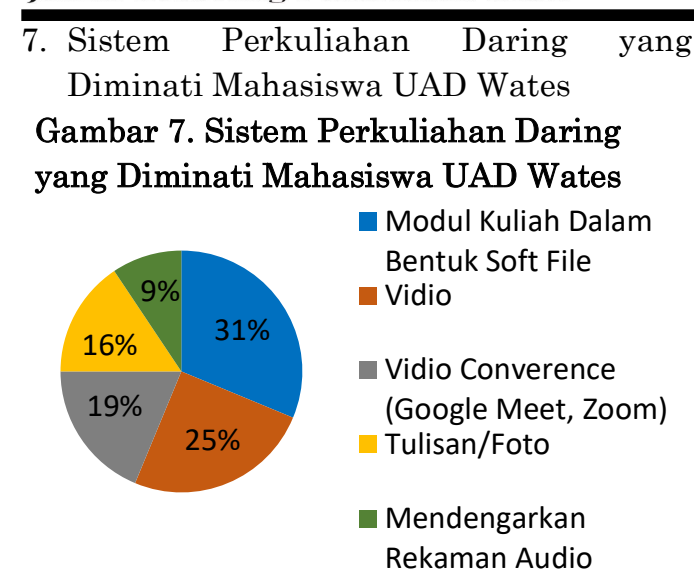

Setiap individu mahasiswa pasti memiliki dan nyaman dengan gaya belajarnya masing-masing. Dari hasil survei diatas diperoleh informasi bahwa $31 \%$ mahaiswa lebih menyukai gaya belajar dengan menggunakan bahan materi kuliah yang dibagikan dalam bentuk visual. Kemudian sebanyak 25\% mahasiswa UAD Wates lebih menyukai gaya belajar yang penyampaian materinya menggunakan video. Selain itu $19 \%$ mahasiswa juga suka mengikuti perkuliahan online dengan menyimak materi melalui video converence dengan Google Meet, Zoom dan lainnya. $16 \%$ lagi lebih suka menyimak materi berupa tulisan atau foto dan 9\% mahasiswa lebih suka mendengarkan rekaman audio.

8. Kendala Mahasiswa UAD Wates Selama Mengikuti Perkuliahan Online
Gambar 8.Sistem Perkuliahan Daring yang Diminati Mahasiswa UAD Wates

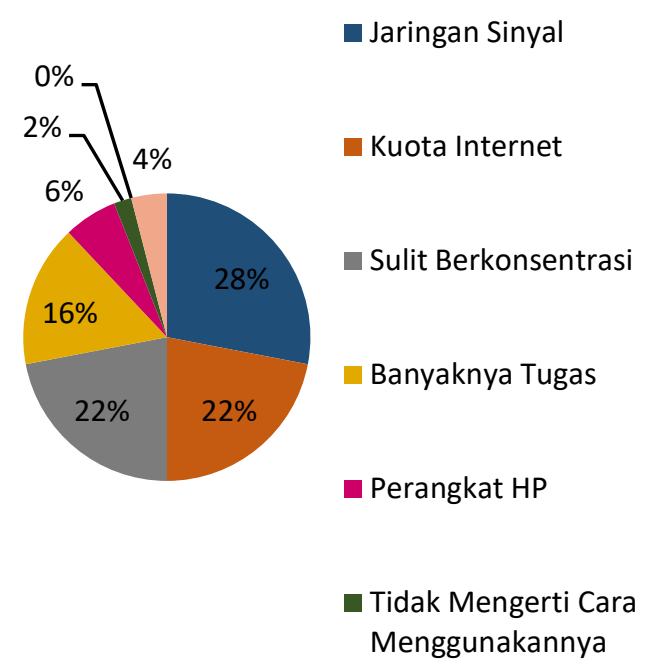

Sementara itu akibat Pandemi Covid-19 ini pemerintah telah mengeluarkan kebijakan untuk mengganti perkuliahan tatap muka menjadi perkuliahan daring. Ternyata kenyataan di lapangan bahwa sebagian besar mahasiswa mengalami hambatan sehingga efektivitas perkuliahan menjadi tidak optimal. Survei dilapangan sesuai dengan grafik diatas, dapat kita ketahui bersama bahwa hambatan paling besar yang dihadapi mahasiswa sebanyak $28 \%$ adalah susahnya jaringan internet atau sinyal. Kemudian 22\% mahasiswa menyatakan banyaknya kuota internet yang dibutuhkan untuk mengikuti perkuliahan online pun menjadi hambatan tersendiri bagi sebagian mahasiswa. Beruntungnya per 28 Oktober 2020 setiap mahasiswa mendapatkan bantuan paket internet sebanyak 5 GB untuk akses seluruh internet dan 45 GB untuk kuota belajar. Akan tetapi pada realisasinya tidak semua mahasiswa bisa merasakan bantuan kuota internet dari kampus tersebut.

Selain susahnya jaringan internet dan borosnya kuota data yang menjadi hambatan mahasiswa mengikuti perkuliahan online, sebanyak $22 \%$ 
$\mathrm{J}_{\mathrm{KF}} \mathrm{F}$

Jurnal Konseling Pendiclikan Islam

mahasiswa juga merasa sulit

berkonsentrasi, karena ketika belajar

dirumah akan ada banyak gangguan yang

sifatnya kurang kondusif, sehingga pikiran

menjadi buyar dan susah fokus. Kemudian sebanyak 16\% mahasiswa menyatakan bahwa banyaknya tugas dengan deadline yang singkat juga menjadi kendala tersendiri, ditambah lagi sebagian dosen ada yang hanya berfokus pada pemberian tugas tanpa diimbangi dengan pemberian materi dan melakukan diskusi. $12 \%$ mahasiswa lainnya mengalami hambatan pada tidak memadainya fasilitas handphone yang dimilikinya, tidak mengerti cara menggunakan aplikasiaplikasi yang digunakan dalam perkuilahan online dan hambatanhambatan lainnya.

\section{SIMPULAN}

Berdasarkan hasil penelitian dan pembahasan diatas maka dapat disimpulkan hal-hal sebagai berikut; Mahasiswa cenderung memilih media pembelajaran yang sudah sangat dikuasai seperti whatsapp, karena fitur-fitur whatsapp yang sangat memudahkan dosen dan juga mahasiswa untuk mengirim dan menerima materi perkuliahan maupun diskusi. Sebagian besar mahasiswa sudah mengetahui media pembelajaran yang digunakan dalam kegiatan perkuliahan online, media pembelajaran yang dimaksud adalah Whatsapp, Zoom, E-learning, Google meet, Google Classroom dan lainnya. Untuk mengikuti perkuliahan online mahasiswa harus mempersiapkan banyak hal, seperti paket/kuota data, handphone, materi, leptop dan sebagainya. Sebagian besar mahasiswa mengikuti perkuliahan online dirumah masing-masing sesuai dengan kebijakan pemerintah untuk belajar dari rumah. Hal ini efektif untuk memutus rantai penyebaran virus Covid-19.
Jurnal Konseling Pendidikan Islam

http://ejournal.alkhairat.ac.id/index.php/JKPI

ISSN: 2655-9692

EISN: 2746-5977

Vol. 2 No. 1, Januari 2021

materi yang disampaikan oleh dosen, akan tetapi terkadang juga tidak paham, terutama materi yang baru pertama kali mereka pelajari apalagi jika tidak disertai dengan penjelasan atau pun diskusi bersama dosen. Mahasiswa lebih menyukai model komunikasi semi 2 arah. Model komunikasi semi 2 arah yang digunakan pada perkuliahan daring UAD Wates yaitu melalui media Chatroom dengan aplikasi Whatsapp. Mahasiswa lebih menyukai bahan perkuliahan yang dibagikan dalam bentuk visual seperti softcopy, file pdf, power point, video, tulisan, foto dan lain sebagainya.

Hambatan paling besar yang dihadapi mahasiswa adalah susahnya jaringan internet atau sinyal, banyaknya kuota internet yang dibutuhkan untuk mengikuti perkuliahan online, susahnya berkonsentrasi, terlalu banyaknya tugas dan lain sebagainya. Sehingga perkuliahan daring ini kurang efektif untuk menambah pemahaman materi mahasiswa UAD Wates.

\section{DAFTARPUSTAKA}

Abidin, J. 2017. RANCANGAN STRATEGI PEMBELAJARAN. Al-Fikra $\square$ : Jurnal Ilmiah Keislaman.

https://doi.org/10.24014/af.v12i1.3863

Firman, F., \& Rahayu, S. 2020. Pembelajaran Online di Tengah Pandemi Covid-19. Indonesian Journal of Educational Science (IJES). https://doi.org/10.31605/ijes.v2i2.659

Hikmat, Hermawan, E., Aldim, \& Irwandi. 2020. Efektivitas Pembalajaran Daring Selama Masa Pandemi Covid19 $\square$ : Sebuah Survey Online. Digital Library, UIN SUnan Gung Djati, Bandung, 1-7. http://digilib.uinsgd.ac.id/30625/

Muhson, A. 2010. PENGEMBANGAN 
MEDIA PEMBELAJARAN BERBASIS TEKNOLOGI INFORMASI. Jurnal Pendidikan Akuntansi Indonesia. https://doi.org/10.21831/jpai.v8i2.949

Putri, R. N. 2020. Indonesia dalam Menghadapi Pandemi Covid-19. Jurnal Ilmiah Universitas Batanghari Jambi.

https://doi.org/10.33087/jiubj.v20i2.101

0

Rohmawati, A. 2015. Efektivitas Pembelajaran. Jurnal Pendidikan Usia Dini. 